\title{
The factors of adaptation of foreign students in the Kaliningrad socio-cultural environment
}

\author{
A. V. Mitrofanova, E. P. Mutavchi, T. N. Stepanova, and I.I. Dragileva \\ Immanuel Kant Baltic Federal University, 14 A. Nevsky St., 236016 Kaliningrad, Russia
}

\begin{abstract}
Regions where universities and research institutes are located are attracting a vast majority of international students. Providing appropriate conditions for the social and cultural adaptation for foreign students to a local culture and social environment of the universities is an urgent issue that requires attention with a scientific approach. In this research authors considered a number of factors affecting social and cultural adaptation of the foreign students. The factors are combined according to the framework of potential challenges: person-person, personenvironment, person-educational organization. In order to overcome these challenges this research suggests a number of initiatives to allow for a successful adaptation of international students to the regional social and cultural environments.
\end{abstract}

\section{Introduction}

Socio-cultural adaptation is a broad concept that implies not only the inclusion of the foreign student in the educational process but also integration in the environment and local culture. The process of socio-cultural adaptation is different for students from different countries. It depends on cultural affinity, the experience of high-level socio-cultural interaction between countries, and other factors. This article presents an analysis of the socio-cultural adaptation of students at Immanuel Kant Baltic Federal University (IKBFU). The received results are aimed at improving the interaction between foreign and Russian students in the educational process and socio-domestic interaction.

\section{Materials and methods}

Many studies are dedicated to socio-cultural adaptation. Ward and Kennedy (1999) introduced the term "Sociocultural adaptation scale" to measure the sociocultural adaptation of foreign students. It's determined by the level of difficulty in the realization of behavioral and cognitive functions faced by people in adapting to a new culture and society. [12]

The sociocultural adaptation is easier for people fluent in the language of the country in which they are studying. (Yang, Noels, \& Saumure, 2006) [13]. Knowing the language of the country of temporary residence is a major factor in successful social interaction and has a positive effect on the process of intercultural communication and understanding the culture and particularities. 
The occurrence of "the cultural shock" condition in the process of socio-cultural adaptation is described in the works of C. Dodd [9], S. Bochner [8], Oberg, K [11] .

Studies of Russian determine different numbers of factors affecting the adaptation of foreign students. For example, A.P. Kormilitsin determines four factors of adaption: physiological, psychological, social, and cultural[4]. Such researchers as S.I. Modnov and L.V. Ukhova determine only three factors: socio-cultural, socio-communicative, and sociodomestic[5]. According to B.N. Abdulakhamidova, students have problems in several respects during adaptation: didactic (teaching, control, self-preparation), psychophysiological (living conditions), socio-psychological (social problems, new community) [1].

E.V. Vitenberg proposes another approach in which foreign students pass three levels of social adaptation: society (macro-environment); social group (micro-environment); intrapersonal adaptation [2]. Z.A. Latipov and other researchers consider psychological, social, and ethnic methods as major methods of adaptation [10].

According to T.V. Pavlushkina and other researchers, the process of adaptation of foreign students is defined by socio-cultural, socio-psychological, and pedagogical aspects. [6].

Approaches mentioned above should be used for the analysis of socio-cultural environment conditions at universities. Due to the increasing availability of education outside of the native country and the possibility of long-term stay on the territory of foreign countries, educational borders are increasingly expanding in the world. Educating abroad ensures competitiveness in the labor market and contributes to beginning a successful career at home. Students from the East go to study in the West, and students from the West show a deep interest in the educational programs of the East.

Students studying in a different culture are aware of the cultural differences in advance but they become fully aware after immersion in a new cultural environment. Foreign students are accommodated in dormitories on general grounds. They go through the intercultural adaptation not only in frames of the educational process but during domestic activities as well. As a result, students experience psychological, social, and cultural stress from the first day of education. The main objective of the university is to properly study and improve the adaptation of international students in order to provide the best educational experience. At the present stage, we have access to the experience of foreign universities on the adaptation of international students, especially those studying in English.

Current Russian leaders in the study of the adaptation of international students are National Research Tomsk Polytechnic University (Tomsk), Peoples' Friendship University of Russia also known as RUDN (Moscow), Lomonosov State University of Moscow, and others. Foreign experience was studied as well.

International activity is one of four key criteria of efficiency of higher education institutions' activity in the long term.

Successful adaptation leads to the expansion of the competencies both of students and teams interacting with them.

The purpose of the study is to identify the strengths and weaknesses of the adaptation of foreign students and to develop recommendations for improving the adaptation.

The methodological basis of this study was the analytical data collected in the 20192020 academic year before the COVID-19 pandemic in Russia. The data was collected by the method of a sociological survey, 75 foreign IKBFU students from 12 countries were offered to fill in the questionnaire. 


\section{Results and discussion}

Immanuel Kant Baltic Federal University attracts foreign students to study at various educational programs and directions. Every year, the interest in getting an education at this university is growing. It can be seen from the statistic data given in Table 1.

Table 1. Number of Russian and foreign students at Immanuel Kant Baltic Federal University (20182020).

\begin{tabular}{|c|c|c|c|c|c|c|c|c|c|c|c|c|c|c|c|c|c|c|c|c|c|}
\hline & \multicolumn{8}{|c|}{2018} & \multicolumn{7}{|c|}{2019} & \multicolumn{6}{|c|}{2020} \\
\hline & 吾 & 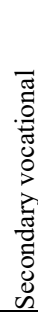 & 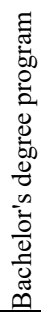 & 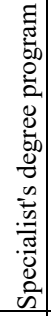 & 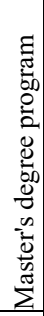 & 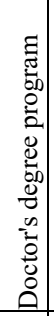 & 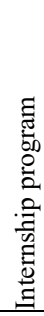 & है & 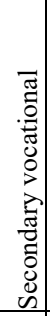 & 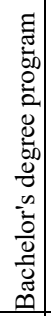 & 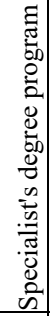 & 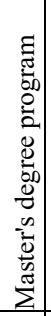 & 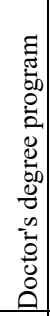 & 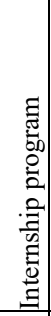 & 吾 & 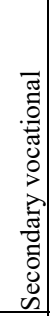 & 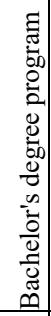 & 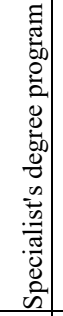 & 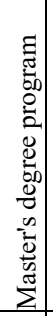 & 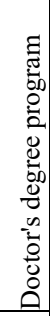 & 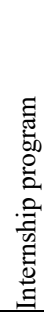 \\
\hline $\begin{array}{l}\text { Stude } \\
\text { nts } \\
\text { that } \\
\text { study } \\
\text { on } \\
\text { terms } \\
\text { of } \\
\text { gener } \\
\text { al } \\
\text { admi } \\
\text { ssions } \\
\text { - total }\end{array}$ & $\begin{array}{l}\bar{b} \\
\stackrel{5}{0}\end{array}$ & 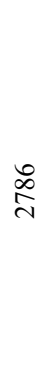 & $\frac{\infty}{\stackrel{\sigma}{\sigma}}$ & 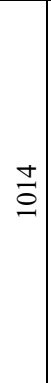 & $\underset{J}{J}$ & $\tilde{f}$ & 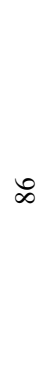 & 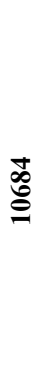 & $\begin{array}{l}\text { \&े } \\
\text { iे }\end{array}$ & 芦 & $\begin{array}{l}\stackrel{0}{\circ} \\
\stackrel{0}{0}\end{array}$ & 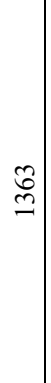 & ஓे & ఠे & ڤั. & $\begin{array}{l}\infty \\
\stackrel{\infty}{0} \\
\end{array}$ & $\stackrel{\vec{\sim}}{\sim}$ & 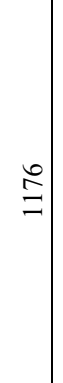 & $\begin{array}{c}\Omega \\
\Omega\end{array}$ & $\stackrel{\infty}{\mathcal{T}}$ & $\bar{m}$ \\
\hline $\begin{array}{l}\text { includ } \\
\text { ing: } \\
\text { citize } \\
\text { ns of } \\
\text { the } \\
\text { Russi } \\
\text { an } \\
\text { Feder } \\
\text { ation }\end{array}$ & $\stackrel{\circ}{\sigma}$ & 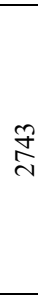 & $\begin{array}{l}\text { है } \\
+\end{array}$ & $\stackrel{\infty}{\infty}$ & 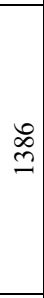 & $\stackrel{\overbrace{}}{+}$ & 8) & ڤ̆ & $\begin{array}{l}\tilde{d} \\
\tilde{N}\end{array}$ & 壱 & $\underset{\infty}{\text { q }}$ & $\stackrel{\approx}{2}$ & $\stackrel{\infty}{\infty}$ & J & శి & 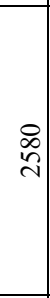 & 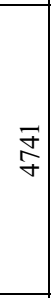 & $\begin{array}{l}\mathbb{d} \\
\infty\end{array}$ & $\frac{\vec{m}}{\underline{n}}$ & $\vec{\sigma}$ & తి \\
\hline $\begin{array}{l}\text { citize } \\
\text { ns of } \\
\text { foreig } \\
n \\
\text { count } \\
\text { ries }\end{array}$ & : & F & $\frac{n}{m}$ & 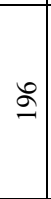 & $\stackrel{\infty}{n}$ & $=$ & $=$ & $\stackrel{\mathbb{N}}{\stackrel{N}{*}}$ & $\bar{F}$ & : & 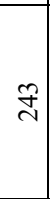 & $\bar{n}$ & $\stackrel{\infty}{\sim}$ & $\simeq$ & $\hat{\sigma}$ & $\stackrel{\infty}{\infty}$ & 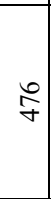 & $\frac{7}{m}$ & $\stackrel{2}{2}$ & $\hat{\imath}$ & $=$ \\
\hline
\end{tabular}

The data from the Table shows the annual increase in the number of foreign students that are pursuing education outside their own country. It's applicable to all levels of education. A small decrease is observed only for secondary vocational education programs.

In order to obtain systematic results of the assessment of students' socio-cultural adaptation, students were differentiated into groups according to regions of arrival. CIS countries are put in a special group because the parents of our students were born in the Soviet Union thus they have equal knowledge of Russian. Besides, there is a permanent intensive migration flow between Russian and CIS countries. 
Table 2. Regions and countries from which foreign students arrive in Immanuel Kant Baltic Federal University.

\begin{tabular}{|l|l|}
\hline \multicolumn{1}{|c|}{ Region } & \multicolumn{1}{|c|}{ Country } \\
\hline North Africa & Morocco \\
\hline South America & Brazil \\
\cline { 2 - 2 } & Peru \\
\cline { 2 - 2 } & Ecuador \\
\hline \multirow{4}{*}{ CIS countries } & Turkmenistan \\
\cline { 2 - 2 } & Tajikistan \\
\cline { 2 - 2 } & Uzbekistan \\
\cline { 2 - 2 } & Kazakhstan \\
\hline Asian countries & Iraq \\
\cline { 2 - 2 } & Iran \\
\cline { 2 - 2 } & Mongolia \\
\cline { 2 - 2 } & India \\
\hline
\end{tabular}

It can be seen from Table 2 that the foreign students studied at the university are not only from the near abroad but from the far abroad as well. There are students from North and South America, and Asia countries.

Table 3. Differentiation of students according to age and gender.

\begin{tabular}{|l|c|c|c|c|}
\hline \multicolumn{1}{|c|}{ Region } & Average age & $\begin{array}{c}\text { Number of } \\
\text { students }\end{array}$ & Female & Male \\
\hline North Africa & 22 & 1 & 1 & - \\
\hline South America & 25 & 12 & 4 & 8 \\
\hline CIS countries & 19 & 10 & 7 & 3 \\
\hline Asian countries & 19 & 52 & 26 & 26 \\
\hline Total & 21 & 75 & 38 & 37 \\
\hline
\end{tabular}

Students from Asian and CIS countries enter university right after finishing school. While the majority of South Americans think about the possibility of obtaining higher education a long period after graduation: the oldest student is 33, the youngest is 18 .

Students from South America are noted to be significantly older than other respondents and paid more attention to studying Russia before arrival: they watched videos on YouTube, read, and studied the Cyrillic alphabet. Most of them note that this information was not useful for adaptation, they had to study in real conditions. They highlighted the winter that is atypical for their region (twice) and a lot of superstitions.

Most of the students come from Asia but only one-third of them pays attention to studying the Russian habits and traditions: some general information from the web encyclopedias, few phrases, and the alphabet. Despite the fact that most respondents note that the Russians help them adapt, staying in Russia as a whole may be represented by the phrase "school of life and discipline". On the other hand, students note the presence of common superstitions, for example, "if a black cat crosses the road you will have to go another way".

According to the Indian students, there are a lot of types of holidays in their country, but they were very surprised that the Russians celebrate the International Women Day and Defender of the Fatherland Day, they are willing to join the Russians on these occasions and proud to tell their relatives about it.

The student from Morocco noted that the culture and habits of the Russians are very different from those of his country, but gave no examples.

We can't say a lot about students from CIS countries as most of them studied in Russian schools or have knowledge of Russian. The traditional way of life in Russia does not cause much surprise, which makes it easier to adapt. 
A block of questions about basic ideas on the culture and traditions in Russia presents both positive and negative impressions of foreign students about Russian citizens of Kaliningrad.

The first group consists of students from South America, most of them are male students older than 23 years. The students of this group generally consider us to be more conservative, closed, and at the same time direct, responsive, and loving our country. Many of the respondents are uncomfortable with the use of alcohol and obscene language by the Russians as it complicates communication in public places. At the same time, the beauty of Russian women is noted, and the Russians are generally considered to be open, communicative, and with good manners.

The largest group is Asian, i.e. students from India. It's obvious that we have a different appearance and it was noted by the students. Mostly, local people made a favorable impression on this group of respondents. Most of the respondents consider the city residents to be stylish, fashion-conscious, and respectable-looking. The Russian language is pleasant to the ear despite the incomprehensibility. At the same time, according to foreign students, the Russians do not smile much, become angry if you don't understand them.

The biggest and most expected problem is the language barrier, in particular the accent, since English is not native to either Asians or Slavs. The second-year students note that the language difficulties are of secondary concern to them.

Bad habits of the Europeans such as smoking and drinking alcohol are unpleasant, but the requirements to keep silent during classes and in the evening, keeping order, and cleanness are also unpleasant.

There are twice as many responses in which students share a positive impression about their stay in Russia. The impressions can be summed up in one phrase: "The Russians welcome guests with love, always ready to help, open-minded for another culture, and have a big heart".

As for the opinion of the students from the CIS countries, we can say that the students did not experience any problems in communicating with the locals, on the contrary, most of them find the residents of Kaliningrad to be as open and friendly as possible. In general, difficulties were connected to independent living at such a distance from the home and the fact that smoking and drinking are socially disapproved in their homeland.

The third block of questions is dedicated to the integration, communication, and social contact levels determination.

Students from South America communicate with the locals at different levels of intensity. Most of them find humor in language and domestic issues, even misunderstanding is taken as a mundane factor easy to put up with: "I have never met my neighbors", "We have no problems because we don't understand each other", etc. Nevertheless, most of them develop friendly relations with the locals of their age and feel quite comfortable: "We are friends with young people", "I'm communicating with the Russians, we will be friends in future, I suppose".

Representatives of Asian countries can be conventionally divided into two groups based on differences in intercultural communication: the first group - Iran, Iraq, Mongolia, the second group - India. Students of the first group feel more comfortable in Russia, more open to communication with the locals, but they don't become close friends with them. They are more open to communication with the locals, but their contacts are superficial. They show greater restraint.

Students from India are friendly but have no close contact with the locals. They are more interested in the attention to their culture from the Russians. The most enthusiastic responses are related to the way the Russians talk about Bollywood, admire their national dances. Students organize India culture days at Immanuel Kant Baltic Federal University 
with great enthusiasm, all interested people are invited to participate in Indian national holidays.

Students from India feel more comfortable communicating with older people, they maintain very close relations with their parents and relatives and may spend hours talking to their parents by video. They are active users of food delivery services, they cooperate to get a taxi to the university.

Girls reply more extensively to the questions of the questionnaire: "When we were shopping the manager was very responsive. Since then this woman always helps us when we go there"; "I lived in the same residential building with the Russian teacher and his family, they are the best people I have ever met. Very caring, friendly and beautiful people". Young men reply in general terms: "Usually the store employees help us, we use Google translator"; "We have good relations with neighbors".

It should be noted that the words "friend" and" be friends " about the Russians with whom foreign students communicate are much more common in the responses of students from South America than in the responses of students from Asia (these are the two largest groups of respondents).

Students from CIS countries don't see the Russians as foreigners because they were raised by the generation that grew up in the Soviet Union. Most of them study in Russian.

In accordance with the results obtained, three groups of factors were identified that determine the complexity of the socio-cultural adaptation of foreign students, which must be taken into account to ensure a comfortable educational environment.

Table 4. Factors influencing the socio-cultural adaptation of students.

\begin{tabular}{|c|c|c|}
\hline Factors & $\begin{array}{l}\text { Conditions for } \\
\text { ensuring } \\
\text { successful } \\
\text { socio-cultural } \\
\text { adaptation }\end{array}$ & $\begin{array}{l}\text { Recommendations } \\
\text { for educational } \\
\text { institutions }\end{array}$ \\
\hline \multicolumn{3}{|c|}{ Difficulty of inter-cultural communication } \\
\hline $\begin{array}{l}\text { socio-cultural contacts (communication and interaction } \\
\text { levels, social circle) }\end{array}$ & \multirow{6}{*}{$\begin{array}{l}\text { establishing } \\
\text { friendly } \\
\text { relations, } \\
\text { ensuring } \\
\text { integration in } \\
\text { frames of } \\
\text { domestic } \\
\text { interaction } \\
\text { (living in a } \\
\text { dorm), } \\
\text { participating in } \\
\text { national } \\
\text { holidays }\end{array}$} & \multirow{6}{*}{$\begin{array}{l}\text { holding joint } \\
\text { activities aimed at } \\
\text { the acquaintance } \\
\text { with the local } \\
\text { culture and culture } \\
\text { of countries from } \\
\text { which the foreign } \\
\text { students came }\end{array}$} \\
\hline The desire to be understood and accepted & & \\
\hline understanding jokes, local humor & & \\
\hline $\begin{array}{l}\text { meeting the needs of performing traditional rites and } \\
\text { customs in the new socio-cultural environment }\end{array}$ & & \\
\hline interaction with unpleasant / agressive people & & \\
\hline $\begin{array}{l}\text { Communication difficulties because of lack of knowledge } \\
\text { of the language }\end{array}$ & & \\
\hline \multicolumn{3}{|l|}{\begin{tabular}{c|c} 
getting acquaintance with the local culture and willing to \\
introduce the native culture to the others
\end{tabular}} \\
\hline \multicolumn{3}{|l|}{ Domestic difficulties } \\
\hline the new rhythm of life & \multirow{7}{*}{$\begin{array}{c}\text { getting } \\
\text { acquaintance } \\
\text { with the new } \\
\text { location in } \\
\text { advance, via } \\
\text { the Internet } \\
\text { sources, media }\end{array}$} & \multirow{7}{*}{$\begin{array}{l}\text { organizing the } \\
\text { volunteer service } \\
\text { helping foreign } \\
\text { students adapt; } \\
\text { providing students } \\
\text { admitted to the } \\
\text { university with } \\
\text { information leaflets } \\
\text { on the local area }\end{array}$} \\
\hline shopping & & \\
\hline using the public transport and taxi & & \\
\hline organization of meals, getting used to the local food & & \\
\hline adaptation to the local climate & & \\
\hline compliance with the local laws & & \\
\hline Safety & & \\
\hline
\end{tabular}


Table 4. Continued.

\begin{tabular}{|c|c|c|}
\hline \multicolumn{3}{|c|}{ Adaptation to the educational environment } \\
\hline $\begin{array}{c}\text { understanding of the requirements of teachers in frames } \\
\text { of subjects taught }\end{array}$ & \multirow{5}{*}{$\begin{array}{c}\text { getting } \\
\text { acquaintance } \\
\text { with the } \\
\text { university } \\
\text { environment, } \\
\text { educational } \\
\text { programs, and } \\
\text { possibilities } \\
\text { for foreign } \\
\text { students in } \\
\text { advance via } \\
\text { internet } \\
\text { sources and } \\
\text { media; } \\
\text { interaction } \\
\text { with fellow } \\
\text { students, } \\
\text { supervisors, } \\
\text { educational } \\
\text { programs } \\
\text { managers, and } \\
\text { methodologists }\end{array}$} & \multirow{5}{*}{$\begin{array}{l}\text { introduction of } \\
\text { educational } \\
\text { programs in English; } \\
\text { active support of } \\
\text { foreign students by } \\
\text { employees of } \\
\text { departments } \\
\text { responsible for } \\
\text { international } \\
\text { cooperation; } \\
\text { ensuring the } \\
\text { supervision of } \\
\text { international } \\
\text { students }\end{array}$} \\
\hline understanding the educational process & & \\
\hline compliance with the rules of the university & & \\
\hline orientation in university buildings & & \\
\hline understanding the class schedule & & \\
\hline
\end{tabular}

\section{Conclusion}

Interpretation of study results obtained allows us to identify factors affecting the sociocultural adaptation of students. These factors can be combined into groups: intercultural communication difficulties, domestic difficulties, difficulties of adaptation to the educational environment. Thus, the foreign student faces the challenges that form the following circle: person-person, person-environment, person-educational institution. Sociocultural adaptation level depends on many factors that affect the foreign student during studying and living in another country. In order to attract foreign students to get an education in Russia, it's necessary to create a supportive environment ensuring the integration of foreign students in the educational process and socio-cultural environment as a whole. An essential condition of ensuring the successful socio-cultural adaptation of foreign students is the implementation by the University of the integrated policy to attract foreign students and organize their educational process. The article provides recommendations for ensuring these conditions.

\section{References}

1. B.N. Abdulakhamidova, Journal of Shadrinsk State Pedagogical University, 3(31), 6 (2016)

2. E.V. Vitenberg, Socio-psychological factors of adaptation to social and cultural changes, 16 (1995)

3. A.D. Gladush, G.N. Trofimova, V.M. Filippov, Socio-cultural adaptation of foreign citizens to the conditions of study and residence in Russia, 146 (2008) 
4. A.P. Kormilitsin, Management of the adaptation process of foreign students in the new economic conditions. Modern scientific and technical problems of civil aviation: abstracts of reports of the International scientific and technical conference, 89 (1996)

5. S.I. Modnov, L.V. Ukhova, Yaroslavl Pedagogical Bulletin, 2(1), 111 (2013)

6. T.V. Pavlushkina, Theory and practice of social development, 15, 70 (2014)

7. T.P. Rakhimov, In the collection of scientific articles: Definitions of culture, collection of works of the participants of the National seminar for young researchers. Tomsk: Publishing house of Tomsk University, 126 (2011)

8. S. Bochner, Cultures in contact: Studies in cross-cultural interaction. Oxford, 123 (1982)

9. C.H. Dodd, Dynamics of intercultural communication (1991)

10. Z. A. Latipov, A. M. Ziyatdinov, L. A. Demidova, V. Gerasimov, M. N. Zaostrovtseva, The problem of adaptation of foreign students studying in Russian universities Especial, 38, 27 (2018)

11. K. Oberg, Practical Anthropology, 29, 142 (2006)

12. Co Ward, A. Kennedy, Journal of Psychology, 28, 129 (1993)

13. R.P. Yang, K.A. Noels, K. D. Saumure, International journal of Intercultural Relations, 30(4), 487 (2006) 